\title{
Edukacja ludności wiejskiej na łamach tygodników społeczno-kulturalnych Królestwa Polskiego po 1864 r.
}

Problem oświaty ludności wiejskiej w II połowie XIX w. był niezwykle istotny. Sama wieś, zwłaszcza po reformie uwłaszczeniowej, zaczęła odgrywać coraz poważniejszą rolę w gospodarce Królestwa Polskiego. Rok 1864 jest więc bardzo istotny, gdyż wprowadzona reforma skutkowała nieodwracalną zmianą dotychczasowej struktury wsi. Chłopi uzyskali wówczas ziemię na własność i stali się prawdziwymi gospodarzami. Skończyły się czasy gospodarowania u pana, a nastały czasy pracy dla siebie. Nieco upraszczając, wcześniej za chłopa myślał pan, a po 1864 r. chłop stanął przed trudnym zadaniem samodzielnego utrzymania swego gospodarstwa. Po uwłaszczeniu nie wystarczyło tylko być właścicielem ziemi, trzeba było „trafnie obmyślić środki działania, przewidzieć przeszkody i obliczyć roztropnie spodziewane skutki. [...] ten przymiot wyrabia się nauką i praktyką [...], ukończenie czterech klas wystarczało, aby objąć majątek [...] ale nie starczało, by go utrzymać..."1.

W tym momencie ujawnił się problem wynikający z wieloletnich zaniedbań pod względem oświaty ludowej. Chłopi byli słabo wykształceni, tę grupę społeczną cechował wysoki poziom analfabetyzmu. Stefan Kieniewicz podawał, że zjawisko to dotyczyło ok. 70\% ludności Królestwa Polskiego, aczkolwiek w niektórych gminach odsetek ten był znacznie wyższy i dochodził nawet do $80 \%{ }^{2}$. Problem analfabetyzmu próbowano rozwiązać za sprawą reform.

Wprowadzona w 1864 r. reforma szkolnictwa była związana z represjami popowstaniowymi, co zaowocowało wprowadzeniem języka rosyjskiego do szkół jako wykładowego. Dodatkowo, program nauczania przepełniony był treściami, które miały przekonać chłopów do systemu carskiego, ukazywano bowiem cara

* Mgr, doktorantka, Katedra Historii Polski XIX w., Instytut Historii, Wydział Filozoficzno-Historyczny, Uniwersytet Łódzki, 90-219 Łódź, ul. Kamińskiego 27a.

${ }^{1}$ L. G ó r s k i, Znaczenie i obowiązki, „Niwa” 1882, t. XXI, s. 258-259.

${ }^{2}$ S. K i e n i e w i c z, Dramat trzeźwych entuzjastów. O ludziach pracy organicznej, Warszawa 1964, s. 146. 
jako przyjaciela ludu, bo to w końcu on doprowadził chłopów do uwłaszczenia i nadał im ziemie.

Środowisko pozytywistyczne szczególnie zwracało uwagę na problem zaniedbania oświaty ludności wiejskiej. Wynikało to z samej filozofii pozytywizmu. Stojąc na gruncie „pracy organicznej” i „pracy u podstaw”, przedstawiciele nurtu pozytywistycznego głośno wypowiadali się o potrzebie niesienia „kaganka oświaty" najuboższym i najbardziej zacofanym. Raził ich wysoki odsetek analfabetyzmu wśród polskich chłopów, który, zdaniem pozytywistów, doprowadził ich do ruiny i był przyczyną wykorzystywania przez dziedziców, urzędników i księży. Zdawali sobie sprawę z tego, że podniesienie poziomu wykształcenia ludności wiejskiej zaowocuje wzrostem gospodarki w skali całego Królestwa Polskiego i podwyższeniem poziomu kultury polskiego społeczeństwa. Dla pozytywistów były to najważniejsze zadania, które można było zrealizować w sytuacji, gdy powstanie styczniowe zakończyło się niepowodzeniem. Pragnęli wzmocnić naród i przede wszystkim dać mu wykształcenie, żeby mógł poradzi sobie w warunkach wzmagającej się rusyfikacji, a w niedalekiej przyszłości - sprostać organizacji niepodległego państwa.

Liberałowie, chcąc ów cel osiągnąć, wykorzystywali prasę jako forum służące prezentacji problemów wynikających z niedostatecznej edukacji. Czasopisma dawały możliwość dotarcia do szerokiego kręgu odbiorców, dlatego też tak chętnie były przez nich wykorzystywane. Wypowiadali się na łamach „Prawdy”, „Niwy”, „Przeglądu Tygodniowego” i „Opiekuna Domowego”. Funkcjonowanie kilku organów prasowych pozytywistów warszawskich było możliwe dzięki temu, że rząd carski tolerował ich działalność na ziemiach Królestwa Polskiego. Mało tego uważał ją nawet za korzystną (przynajmniej w pewnym stopniu) dla państwa rosyjskiego, rząd carski szukał bowiem w społeczeństwie polskim porozumienia z tymi warstwami społecznymi, które mogły popierać jego politykę lub pozostałyby neutralne. Uważał więc, że uda się nawiązać współpracę z chłopami i mieszczanami, a pozytywiści występowali właśnie w ich imieniu ${ }^{3}$.

Pierwszym organem pozytywistów był założony i redagowany przez kilkadziesiąt lat przez Adama Wiślickiego „Przegląd Tygodniowy”. Ukazywał się od 1866 r. Wiślicki skupiał wokół siebie grupę młodych pozytywistów, przeważnie inteligentów oraz studentów. Wkrótce rozpoczęły się jednak spory i nastąpił rozłam w wydawnictwie. W 1872 r. umiarkowani pozytywiści, którzy byli niezadowoleni z poczynań swych bardziej radykalnych kolegów, założyli „Niwę”. Zbiegło się to z odejściem kolejnej grupy powściągliwych pozytywistów do „Opiekuna Domowego". Jednakże największą rolę odgrywała „Prawda” Aleksandra Świętochowskiego, powołana do życia na początku lat osiemdziesiątych XIX w. Periodyk ten miał charakter społeczno-polityczny i kulturalny. Publicyści „Prawdy” jako najważniejszy cel stawiali sobie walkę z zacofaniem umysłowym, propagowanie nauki i szeroko rozumianej oświaty. Redaktor pisma zamieszczał co tydzień felieton Liberum veto, w którym dość ostro komentował i krytykował różne negatywne zjawiska występujące w kulturze i obyczajowości społeczeństwa polskiego. Na łamach pisma ukazywało się również wiele ciekawych artykułów na tematy literackie oraz

${ }^{3}$ A. J a s z c z u k, Spór pozytywistów z konserwatystami o przyszłość Polski 1870-1908, Warszawa 1968, s. 44. 
informacje na temat prac wybitnych badaczy, reprezentujących różne dziedziny wiedzy. Redakcja czasopisma kładła nacisk na popularyzowanie najważniejszych osiągnięć nauki, propagowanie wiedzy i - co najważniejsze - postulowała powszechność oświaty ${ }^{4}$.

Podobne stanowisko zajmowali tradycjonaliści. Konserwatyści musieli się uaktywnić, ponieważ na arenę społeczną wkroczyło pokolenie pozytywistyczne, postanowili więc rozpocząć z nimi polemikę prasową. Ich organa prasowe to „Kronika Rodzinna”, „Niwa” i „Słowo”. „Kronikę Rodzinną” pozyskali już w 1873 r. Ten dwutygodnik poświęcał przede wszystkim miejsce sprawom dotyczącym wychowania dzieci i zarządzania gospodarstwem domowym. Większe znaczenie w kręgach tradycjonalistycznych zaczęła odgrywać „Niwa”, gdy konserwatyści doszli do porozumienia z umiarkowanymi pozytywistami (1875). Była ona periodykiem skierowanym do dość wąskiej grupy wykształconych czytelników, wywodzących się głównie z warstwy ziemiańskiej i inteligenckiej. Redakcja pisma dowodziła doniosłej roli dziedziców w życiu całego narodu i odwoływała się do tradycji historycznej ${ }^{5}$. Najważniejszym pismem konserwatystów było „Słowo”, ukazujące się od 2 stycznia 1882 r. pod redakcją Juliusza Niemirycza. Wkrótce jednak periodyk ten przeszedł pod kierownictwo Henryka Sienkiewicza i oprócz problemów społecznych oraz politycznych zaczął podejmować tematykę związaną z kulturą.

W niniejszej pracy skupiłam się na tych periodykach, które skierowane były do inteligencji (ówczesna inteligencja to także ziemianie, tzw. inteligencja wiejska, jak pisali pozytywiści i duchowni). Dlatego też podejmowane przez te tygodniki kwestie dotyczące edukacji mieszkańców wsi poruszane były na zasadzie sugestii, co warstwy oświecone, mające z chłopami kontakt, powinny robić, aby podnieść ogólny poziom ich edukacji.

Na łamach swych organów prasowych środowisko liberalne wypowiadało się przede wszystkim na temat rozpowszechniania wiedzy wśród najmniej wykształconych, stąd też zainteresowanie edukacją ludową, którą uważano za niezwykle istotną i ważną. Przedstawiciele tych kręgów wierzyli, że dając rzetelne wykształcenie mieszkańcom wsi będzie można włączyć ich w proces tworzenia nowoczesnego społeczeństwa, opartego na zasadach solidaryzmu społecznego.

Zanim pojawiły się konkretne pomysły dotyczące podniesienia poziomu edukacji, pozytywiści wskazywali przyczyny dotychczasowego niskiego poziomu oświaty na prowincji. Ubolewali nad tym, że na wsiach, co prawda, działały szkółki elementarne, ale - jak już wspomniałam na początku - obowiązywał w nich język rosyjski, który skutecznie odstraszał chłopów od szkoły. Hipolit B. Tarczyński właśnie w języku obcym widział powód niskiego poziomu wykształcenia włościan ${ }^{6}$. Była to istotna zapora, gdyż chłop nie mógł niczego się nauczyć, zanim nie opanował dostatecznie języka zaborcy. Dla mieszkańców wsi była to bariera bardzo często nie do pokonania, najczęściej z pobudek mentalnych.

$\mathrm{Na}$ łamach prasy pobrzmiewały również słowa krytyczne wobec zbyt wielkiej, zdaniem pozytywistów, roli religii w szkołach ludowych. Z racji swej ideologii,

\footnotetext{
${ }^{4}$ Z. K m i e c i k, Prasa polska w latach 1864-1918, Warszawa 1976, s. 36.

5 Tamże, s. 37.

${ }^{6}$ H. B. Ta r c z y ń s k i, Czemu nasz chłop ciemny, „Prawda” 1882, nr 17, s. 203.
} 
z jednej strony pozytywiści pragnęli szkoły bezwyznaniowej, z drugiej bardzo liczyli na pomoc księży w procesie szerzenia oświaty. Należy pamiętać, że duchowni cieszyli się autorytetem w swym środowisku i chłopi bardzo często zwracali się do nich z prośbą o pomoc i wsparcie. Dzięki temu księżom najłatwiej było dotrzeć do niewykształconego ludu.

Publicyści ubolewali również nad brakiem zrozumienia rodziców dla idei kształcenia dzieci, które zatrudniali na roli, zamiast posyłać do szkoły. Dodatkowo zbyt mała liczba szkół ludowych powodowała, że w okresach zimowych, kiedy panowały niekorzystne warunki na drogach, dzieci pozostawały w chatach, gdyż znaczna odległość skutecznie je odstraszała i zniechęcała. Pisząc o wadach szkół ludowych, pozytywiści zwracali także uwagę na brak odpowiedniej kadry nauczycielskiej. Wynikało to głównie z niskiego uposażenia nauczycieli wiejskich oraz braku autorytetu w tym środowisku. Pisano wprost, że nauczyciele traktowani byli przez mieszkańców jako zbędny balast, który obciążał finansowo gminę (w wyniku reformy oświaty z 1864 r. koszty utrzymania szkół ludowych zostały przeniesione na gminy i gromady) ${ }^{7}$. Możliwości uzdrowienia dotychczasowego procesu edukacji ludności wiejskiej publicyści upatrywali w dwutorowym rozwijaniu oświaty - szkolnej i pozaszkolnej.

Jeżeli chodzi o tę drugą, to na łamach prasy proponowano m.in., aby podjąć się pisania specjalnych książek i wydawania pism, które byłyby skierowane bezpośrednio do włościan. Dotychczasowe publikacje „Iudowe”, takie jak np. „Zorza”, miały wydźwięk moralizatorski i umoralniający. Pozytywiści chcieli zamieszczać w tych wydawnictwach więcej rad praktycznych i nowinek technicznych, dzięki czemu chłopi częściej sięgaliby po pisma drukowane. Dodatkowym atutem periodyków skierowanych do prostego ludu miało być redagowanie ich przez osoby, dla których środowisko wiejskie nie jest obce, czyli wywodzące się ze wsi bądź z nią blisko związane. Pozytywnie odbierano książki pisane przez Kazimierza Promyka (Prószyńskiego) i Władysława Ludwika Anczyca ${ }^{8}$, „[...] Najprzód powiększyła się liczba książek pożytecznych dla ludu przeznaczonych; dalej, jak wiadomo, ogłoszono konkurs na «książkę popularną dla włościan», a wreszcie znalazło się kółko ludzi pragnących wziąć inicjatywę w wydawnictwie "tanich książek ludowych»"9.

Istotnym elementem edukacji ludności wiejskiej miało być również zakładanie ochronek dla dzieci, bardzo często pozostających bez opieki dorosłych, którzy udawali się $w$ tym czasie do pracy na roli. Publicyści donosili o tragicznych skutkach takiej nieodpowiedzialności ze strony rodziców. Aleksander Świętochowski proponował, aby dostosować się do zaleceń generał-gubernatora warszawskiego w sprawie zakładania ochronek przez gromady ${ }^{10}$. Ochronki miały spełniać, zdaniem pozytywistów, niezwykle ważne zadania na terenie tych wsi, gdzie nie było szkół elementarnych - wychowywać dzieci i kształtować ich zainteresowania od najmłodszych lat.

${ }^{7}$ H. B rodow s k a, Ruch chłopski po uwłaszczeniu w Królestwie Polskim 1864-1904, Warszawa 1967, s. 194.

8 J. K i t a, Formy „wychowania i umoralniania” chłopów propagowane na łamach pism pozytywistów warszawskich (do 1886 r.), „Acta Universitatis Lodziensis” 1995, Folia historica 52, s. 61.

${ }^{9}$ Rok 1879, „Niwa” 1880, t. XVII, s. 4.

${ }^{10}$ A. Ś w i ę t o c h o w s k i, Liberum veto, „Prawda” 1881, nr 21, s. 250. 
Ważnym elementem edukacji na łamach prasy było także wykształcenie wśród ludności wiejskiej potrzeby dbania o własne zdrowie. Proponowano, aby gminy zatrudniały lekarzy, którzy otrzymywaliby pensje finansowane przez ich mieszkańców. Publicystom chodziło głównie o to, aby lud przestał korzystać z pomocy znachorów i felczerów, a zaczął wierzyć i ufać prawdziwym lekarzom. Problem zdrowia i opieki zdrowotnej był uznawany za bardzo pilny, dlatego wiele pisano na ten temat.

Niezwykle odpowiedzialne zadanie niesienia „kaganka oświaty” na wsi pozytywiści nałożyli przede wszystkim na warstwę ziemiańską, uważali bowiem, że jej przedstawiciele powinni pokierować edukacją ciemnego ludu z racji pozycji, zajmowanej w społeczności wiejskiej. Warto przy tym zwrócić uwagę na fakt, że początkowo negatywnie postrzegali ziemiaństwo, gdyż upatrywali w nim spadkobierców szlachty, którą oskarżali o doprowadzenie do upadku państwa polskiego. Dopiero gdy zauważyli, jak bardzo pożyteczną, a zarazem ciężką pracę prowadzi ta grupa społeczna na wsi, wśród najbiedniejszych i najmniej wykształconych, zmienili swoje nastawienie do niej. Doceniali wkład polskiego dworu w działalność patriotyczną, polegającą na krzewieniu polskich wartości i tradycji. Jednocześnie pozytywiści dostrzegli, że w rzeczywistości ziemiaństwo jest ich wielkim sojusznikiem w nierównej walce o „lepsze jutro” dla całego uciśnionego narodu polskiego. $Z$ tego też względu, propagując na łamach prasy pomysły podniesienia poziomu oświaty, zwracali się do przedstawicieli inteligencji wiejskiej. Zdaniem publicystów, miała ona za zadanie niwelować dysproporcje dotyczące wykształcenia, bo „tylko klasy oświecone mogą i muszą wziąć inicjatywę w oświecaniu klas ciemnych"11.

Niezwykle istotne było to, że pozytywiści zaczęli postrzegać uprawę roli w kategoriach pracy zawodowej, dlatego też akcentowali rozszerzanie wiedzy praktycznej. Redakcja „Przeglądu Tygodniowego” apelowała do obywateli ziemskich, uznanych za wzorowych gospodarzy, aby ci otwierali u siebie praktykę dla młodych i zdolnych, chcących zdobyć doświadczenie w zawodzie rolnika ${ }^{12}$.

Publicyści uważali, że zakładanie szkół wiejskich powinno być dotowane przez prawych ziemian, do nich samych powinna należeć inicjatywa tworzenia takich placówek ${ }^{13}$. Podobnie rzecz się miała z zakładaniem bibliotek i czytelni, bardzo pożytecznych w środowiskach wiejskich. Zapał do pracy społecznej miał wynikać z potrzeby serca, a nie z porywu chwili, bo wówczas nie przynosi pożądanych rezultatów ${ }^{14}$. Zakładanie czytelni składkowych było niezwykle cenione, dlatego też chwalono ów sposób szerzenia oświaty wśród współmieszkańców gminy.

Pozytywiści zdawali sobie sprawę, że szerzenie oświaty na wsi powinno się zacząć od rzetelnej edukacji dziedziców. Było to logiczne, bo przecież od nich zależały losy ciemnego pospólstwa, a nie mając wykształcenia nie mogli kształcić innych. Rola ziemiaństwa w kwestii edukacji wiejskiej była więc bardzo znacząca, gdyż

11 L. M i k u I s k i, Praca u podstaw, „Przeglą Tygodniowy” 1873, nr 12, s. 113.

12 Praktykanci rolni, „Przegląd Tygodniowy” 1869, nr 20, s. 179.

${ }^{13}$ W perspektywie, „Prawda” 1881, nr 47, s. 562-563.

14 Zob. „Prawda” 1883, nr 25, s. 299. 
oświata ludowa była niezmiernie zaniedbana. Józef Karol Potocki, piszący pod pseudonimem Maryan Bohusz, na łamach „Prawdy” daje przykry obraz polskiej wsi:

Gospodarz mój uśmiechnął się i rzekł: od czasu opuszczenia 3 klasy gimnazjum, do czego skłoniła mię moja dzisiejsza połowica - dwa razy tylko miałem pióro w ręku: raz, kiedy żona kazała smarować żółtkiem jakieś placki, a potem, kiedy, zgubiwszy drewnianą wykałaczkę, musiałem wydobyć z pomiędzy zębów kawałek zimnej baraniny ${ }^{15}$.

Nie był to optymistyczny widok, ale niestety dość popularny, jeszcze w drugiej połowie XIX w. W jednym z felietonów na łamach "Przeglądu Tygodniowego" czytamy:

[...] gdyby nasi gospodarze posiadali gruntowniejsze wartości teoretyczne, postęp rolniczy z nich krzewiłby się szybciej, gdyż każdy z nich miałby w ręku klucz do wytłumaczenia sobie zjawisk, praktyki, rozumiał je i zaradzał stosownie ${ }^{16}$.

Za niezwykle ważne - jeśli chodzi o pozaszkolne rozpowszechnianie oświaty na wsi - uważano (czemu dawano wyraz na szpaltach prasy) organizowanie wystaw rolniczych, jarmarków wełnianych czy też wyścigów konnych ${ }^{17}$. Eksponowano zaangażowanie samych chłopów $w$ te przedsięwzięcia ${ }^{18}$. Był to niezwykle istotny element edukacji rolniczej, dzięki któremu uczyli się racjonalnego i nowoczesnego gospodarowania. Tematyczne wystawy rolnicze stanowiły dla chłopów źródło cennej wiedzy praktycznej, którą mogli wykorzystywać bezpośrednio w swoich obejściach.

Konserwatyści podobnie widzieli kwestię szerzenia oświaty. Na łamach „Niwy” i „Słowa” można było spotkać głosy podobne do tych pozytywistycznych. Dla przedstawicieli środowiska konserwatywnego również olbrzymie znaczenie miało organizowanie zebrań rolniczych, stąd też liczne doniesienia w ich prasie o tych pozytywnych działaniach dziedziców ziemskich. Były bardzo istotne, ponieważ ich uczestnicy mogli udzielać sobie rad i wskazówek, wymieniać się spostrzeżeniami i doświadczeniami. Wspólnie prenumerowali pisma rolnicze, z których odczytywano referaty i artykuły. Podczas spotkań powstawały inicjatywy tworzenia bibliotek rolniczych, kupowania nasion itp.

Publicyści konserwatywni, podobnie jak pozytywistyczni, uważali, że obowiązek nauczania spoczywa na tych, którzy najczęściej spotykają się z powszechnym na wsi analfabetyzmem. „Nikt nie zaprzeczy, że dla posiadaczy większych - nie tylko w rzeczach publicznego dobra, ale i w pracy ich własnego pożytku dotyczących - ciemnota ludu stanowi tak silną zaporę, iż o nią najlepsze chęci i najsilniejsze zabiegi rozbijać się muszą"19.

Prasa konserwatywna była bardzo czuła na wszelkie przejawy zaangażowania na rzecz ludu, w związku z czym wiele takich przejawów opisywała:

\footnotetext{
${ }^{15}$ M. B o h u s z [J. K. Potocki], Na widnokręgu, „Prawda” 1881, nr 15, s. 178

16 Echa warszawskie, „Przeglad Tygodniowy” 1900, nr 31, s. 325.

17 A. Ś w ię to c h o w s k i, Liberum veto, Prawda 1881, nr 25, s. 298.

18 M. B o h u s z, Na widnokręgu, s. 45.

19 J. J e l e ń s k i, W sprawie oświaty ludu, „Niwa” 1877, t. XII, s. 881.
} 
Chwalebny zwyczaj zaprowadziła u siebie jedna z obywatelek wiejskich. Pani ta jest nader uczynną dla ludu, wśród którego wychowała się i wzrosła, i który kocha serdecznie. Ale też dlatego właśnie oświadczyła mieszkańcom swej wioski, że ktokolwiek zechce zgłosić się do niej czy to o radę jakąś, czy też o zapomogę [...] nie może wystąpić z żądaniami swemi inaczej, jeno na piśmie. Że zaś interesantów udających się do „swej dobrej pani” nigdy nie brakowało i nie brakuje, przeto nauka czytania i pisania musiała pójść w górę ${ }^{20}$.

Niewątpliwie to innowacyjne podejście do kwestii szerzenia oświaty wśród włościan przypadło do gustu samym zainteresowanym i zyskało ich aprobatę. Dodatkowo, tradycjonaliści próbowali rozwiązać problem zaniedbania oświaty wiejskiej poprzez podejmowanie różnorakich przedsięwzięć na niwie społecznej. Pragnęli, „ażeby każda wieś miała szkółkę, gimnastykę, filiję kasy oszczędności, stację meteorologiczną, salę zabaw, czytelnię, ochronkę i kilka najpotrzebniejszych warsztatów rzemieślniczych pod ręką"21.

$\mathrm{Na}$ łamach konserwatywnej prasy można było spotkać pochwały pod adresem panów, którzy decydowali się na własny koszt utrzymywać szkółkę wiejską. Często donoszono również o bardzo popularnych wspólnych działaniach dworów w danej okolicy, które polegały na tym, że jeden ziemianin przekazywał drzewo, inny ofiarował grunty, a jeszcze inny zobowiązywał się do opłacania pensji nauczycielowi w szkole ludowej ${ }^{22}$.

Istotnym faktem było też zaangażowanie się ziemian w działalność samorządową. Aktywność społeczna tego typu miała uczynić z chłopów warstwę oświeconą, świadomą swej pozycji i siły w społeczeństwie. Krokiem do realizacji wskazanego założenia miało być zdobycie zaufania włościan, którzy mieli decydować o powierzeniu określonej osobie urzędu wójta, pełnomocnika kasjera, a przede wszystkim sędziego gminnego ${ }^{23}$.

Publicyści, niezależnie od swej ideologii, chętnie chwalili wzorowych dziedziców, którzy przyczyniali się do upowszechniania choćby namiastki edukacji na wsi. Miało to służyć szukaniu następców i działaniom zmierzającym do upowszechnienia oświaty. Często stawiano za wzór również samych chłopów, którzy wykazywali szczególne chęci do nauki:

Chciałbym, ażeby wychowaniec mój posiadał te przymioty, jakimi się odznaczał Józef Buchta, służący przy dworze we wsi Sędzicach. Nauczywszy się czytać i pisać [...] pochłonął wszystkie książki dzieci dworskich. Pewnego dnia dziedzic odbiera od Buchty bardzo porządnie napisany list, w którym on prosi o dopomożenie mu w sprowadzaniu gazety świątecznej, mianowicie żąda, aby z dwóch bochenków chleba, które co tydzień odbiera ze dworu, dawać mu tylko jeden, a drugi przeznaczać na... prenumeratę gazety. Naturalnie dziedzic chleba nie zmniejszył i pismo dzielnemu chłopu zaprenumerowat ${ }^{24}$.

Pomimo pochwał skierowanych do zacnych ziemian czy samych chłopów, konserwatyści dopatrywali się braków w wychowaniu i wykształceniu niektórych

${ }^{20}$ Rozmaitości, „Niwa” 1878, t. XIII, s. 655.

21 Sprawy bieżące, „Niwa” 1875, t. VII, s. 17.

22 Rozmaitości, s. 883.

${ }^{23}$ Zob. G. W i e r c i ń s k i, Gmina w obecnym i możliwym ustroju, „Niwa” 1877, t. XII, s. 84-94.

${ }^{24}$ W perspektywie, „Prawda” 1882, nr 6, s. 69-70. 
dziedziców. Na łamach prasy często drwiono z kosmopolitycznego podejścia do edukacji dzieci z ziemiańskich rodzin. Jedną z przyczyn upadku wielkich majątków była zbytnia dbałość o ogólny rozwój na niekorzyść tak ważnej edukacji rolniczej. Konserwatyści ubolewali, że niektórzy ziemianie obrali zły kierunek wychowywania swych synów, przez co może zabraknąć w przyszłości ich następców zainteresowanych sprawami agrarnymi:

Pewien młody człowiek, świetnie wychowana ozdoba salonów, strasznie pod względem humanistycznym wykształcony, pełen rozlicznych zalet i przymiotów, mogący dość gruntownie rozprawiać o archeologii, sztuce i literaturze w dwu starożytnych i pięciu nowożytnych językach, odziedziczył po ojcu pyszny majątek ziemski w cenie szacunkowej 105000 rs. i z górą 75000 rs. gotówki. Było to przed 18-tu laty; dziś - stan jego majątkowy wynosi kilkanaście tysięcy rs. pasywów! Jakaż tego przyczyna? Oto ta, że nasz zacny i przez wszystkich kochany sąsiad, nierównie lepiej rozróżniał pisownię Erasmus od Reuchlina, niż pszenicę od żyta, a zajmując się mieszkańcami, narodami przedhistorycznymi i jaskiniami Proglodytów, zapomniał zupełnie o stajniach i oborach, o sługach i służebnicach ${ }^{25}$.

Niewątpliwie, niektóre rozwiązania proponowane przez publicystów, dotyczące oświaty ludności wiejskiej pozostawały w sferze utopii. Chodzi przede wszystkim o zakładany zbyt duży udział warstwy ziemiańskiej w trudnym procesie edukacji ludu wiejskiego. Zarówno środowiska pozytywistyczne, jak i konserwatywne złożyły na barki inteligencji wiejskiej poważny ciężar, któremu nie mogła do końca podołać, często z braku wolnych środków w dochodach uzyskiwanych z przeżywających kryzys majątków ziemskich po uwłaszczeniu. Ponadto niejednokrotnie niechęć ziemiaństwa do pomocy chłopom na niwie oświatowej stanowiła wynik panującej pomiędzy tymi warstwami obopólnej wrogości. Jeszcze inną kwestią był brak zrozumienia dla nauczania dzieci przez pokolenie dawnych chłopów pańszczyźnianych.

Sam fakt, że publicyści pism różnych odłamów ideowych dostrzegali problem bardzo poważnego zaniedbania edukacji na wsi, jest zjawiskiem bardzo istotnym. Wskazywano przyczyny tego stanu rzeczy i wysuwano propozycje dotyczące podniesienia poziomu wykształcenia, co świadczy o tym, że zaczęto interesować się oświatą ludową na szeroką skalę. Próba społecznej reformy edukacyjnej obejmowała także ludność wiejską, a prasa miała niebagatelne znaczenie w popularyzacji oświaty w kraju pozbawionym własnego szkolnictwa, zdanym na politykę władz zaborczych.

25 Sprawy bieżące, „Niwa” 1875, t. IX, s. 810. 